UCRL-JC-125220

PREPRINT

\title{
Lightweight Pressure Vessels and Unitized Regenerative Fuel Cells
}

\author{
F. Mitlitsky \\ B. Myers
}

A. H. Weisberg

This paper was prepared for submittal to the

1996 Fuel Cell Seminar

Kissimmee, FL

November 17-20, 1996

September 6, 1996

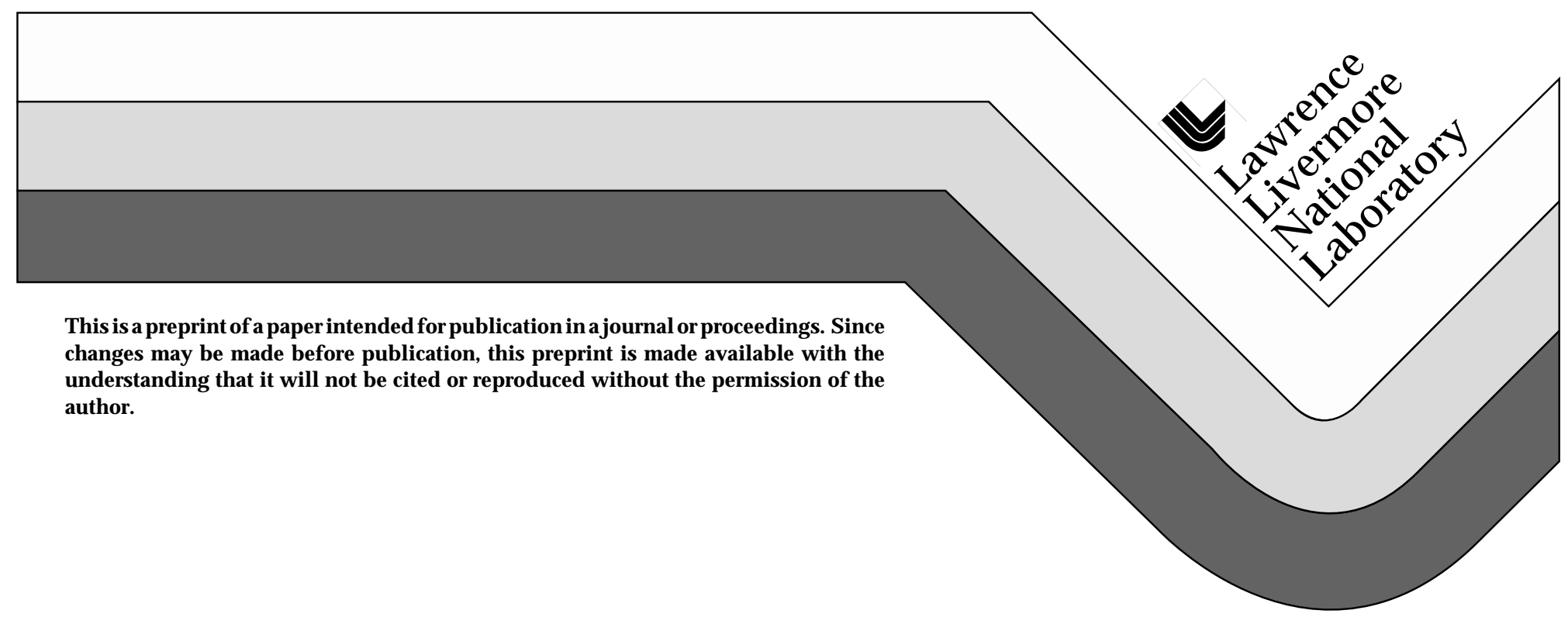




\section{DISCLAIMER}

This document was prepared as an account of work sponsored by an agency of the United States Government. Neither the United States Government nor the University of California nor any of their employees, makes any warranty, express or implied, or assumes any legal liability or responsibility for the accuracy, completeness, or usefulness of any information, apparatus, product, or process disclosed, or represents that its use would not infringe privately owned rights. Reference herein to any specific commercial product, process, or service by trade name, trademark, manufacturer, or otherwise, does not necessarily constitute or imply its endorsement, recommendation, or favoring by the United States Government or the University of California. The views and opinions of authors expressed herein do not necessarily state or reflect those of the United States Government or the University of California, and shall not be used for advertising or product endorsement purposes. 


\title{
LIGHTWEIGHT PRESSURE VESSELS AND UNITIZED REGENERATIVE FUEL CELLS
}

\author{
F. Mitlitsky, B. Myers, and A.H. Weisberg \\ Lawrence Livermore National Laboratory \\ 7000 East AVE, P.O. Box 808, L-045 \\ Livermore, CA 94551-0808
}

High specific energy (>400 Wh/kg) energy storage systems have been designed using lightweight pressure vessels in conjunction with unitized regenerative fuel cells (URFCs). URFCs produce power and electrolytically regenerate their reactants using a single stack of reversible cells. Although a rechargeable energy storage system with such high specific energy has not yet been fabricated, we have made progress towards this goal. A primary fuel cell (FC) test rig with a single cell $\left(0.05 \mathrm{ft}^{2}\right.$ active area) has been modified and operated reversibly as a URFC. This URFC uses bifunctional electrodes (oxidation and reduction electrodes reverse roles when switching from charge to discharge, as with a rechargeable battery) and cathode feed electrolysis (water is fed from the oxygen side of the cell). Lightweight pressure vessels with state-of-the-art performance factors (burst pressure * internal volume / tank weight $=\mathrm{Pb} V / W$ ) have been designed and fabricated. ${ }^{[1]}$ These vessels provide a lightweight means of storing reactant gases required for fuel cells (FCs) or URFCs. The vessels use lightweight bladder liners that act as inflatable mandrels for composite overwrap and provide the permeation barrier for gas storage. The bladders are fabricated using materials that are compatible with humidified gases which may be created by the electrolysis of water and are compatible with elevated temperatures that occur during fast fills.

Lightweight vessels have been designed and fabricated to react purely pressure loads or hybridized pressure and structural loads. Use of these hybridized vessels can result in lower system mass for various vehicles, such as high altitude long endurance (HALE) solar rechargeable aircraft (SRA). ${ }^{[2]}$ We have designed, fabricated, and load tested to failure (in bending) a series of prototype hybridized vessels that can withstand the structural loads expected in a HALE SRA, in addition to storing the reactant gases required by a URFC energy storage system.

URFC systems with lightweight pressure vessels were designed for zero emission vehicles (ZEVs). Such systems are shown to be cost competitive with primary FC powered vehicles that operate on hydrogen/air with capacitors or batteries for power peaking and regenerative braking. URFCs are capable of regenerative braking via electrolysis and power peaking using low volume/low pressure accumulated oxygen for supercharging the power stack. ${ }^{[3]}$ URFC ZEVs effectively carry their infrastructure on-board, enabling electrical recharge at home, work, or the highest power electric vehicle charging stations under consideration (by virtue of the large active area of cells that are sized for power production). URFC ZEVs can be safely and rapidly ( $<5$ minutes) refueled from high pressure hydrogen sources, when available, to achieve driving ranges in excess of 350 miles. URFC ZEVs can be refueled using home electrolysis units, but procurement of such units becomes an option, rather than a requirement, as is the case of other hydrogen powered vehicles prior to the existence of a widespread hydrogen infrastructure.

A single cell cycle life test for a URFC showed that reversible operation of cell membrane and catalyst is feasible without significant degradation, ${ }^{[4]}$ thus refuting comments to the contrary made at the 1994 Fuel Cell Seminar. This test was performed in the early 1970s at ambient temperature using a membrane that is similar to DuPont's Nafion 120 . The catalyst $\left(\mathrm{E}-5^{\mathrm{TM}}\right)$ is a proprietary General Electric mixture of Pt, Pt-group metals, and their oxides. This test was a proof-ofprinciple energy storage system for a long life (7-10 yr) geosynchronous satellite, that was required not to use mechanical pumps (for reliability). The cell used a wicking cloth (typically quartz or Dacron) to feed water to the cell in zero-gravity. Upon disassembly of the cell, the initially hydrophilic wicks had become hydrophobic which degrades wicking and may well account for most of the limited cell degradation $(<40 \mathrm{mV})$ shown in figure 1 . It should be noted that other substitutes for wicks exist for zero-gravity operation, and wicks are clearly not required for terrestrial applications. Since this early data is sparse and masked by the unnecessary wicking cloth, we plan to perform a series of lifetime tests to show that high cycle life URFCs are feasible. 
MITLITSKY ET AL

-2 -

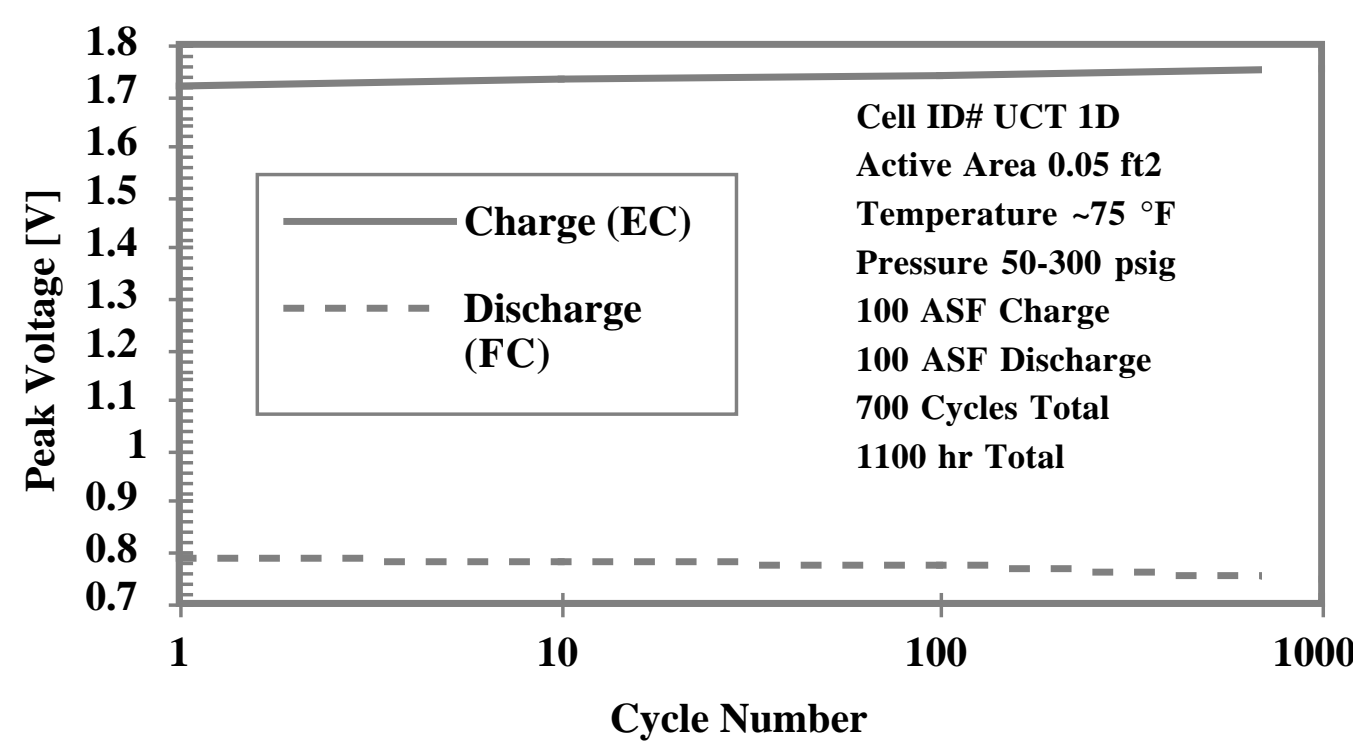

Figure 1. A URFC cycle life test shows less than $40 \mathrm{mV}$ degradation over 700 cycles (1100 hr). [4]

\begin{tabular}{|c|c|c|c|}
\hline $\begin{array}{l}\text { Battery/URFC } \\
\text { System }\end{array}$ & $\begin{array}{c}\text { Theoretical Specific } \\
\text { Energy [Wh/kg] }\end{array}$ & $\begin{array}{c}\text { Packaged Specific } \\
\text { Energy }[\mathrm{Wh} / \mathrm{kg}]\end{array}$ & Comments \\
\hline $\mathrm{H}_{2} / \mathrm{O}_{2} \mathrm{URFC}$ & 3660 & $400-1000$ & $\begin{array}{l}\text { URFCs with lightweight } \\
\text { pressure vessels }\end{array}$ \\
\hline $\mathrm{Zn} / \mathrm{O}_{2}$ & 1035 & 250 & $\begin{array}{l}\text { Excess } \mathrm{Zn} \text { required, } \\
\text { poor cycle life, dry-out }\end{array}$ \\
\hline Li-SPE/MO ${ }_{x}^{*}$ & 735 & 220 & $\begin{array}{l}\text { Novel packaging for } \\
\text { unmanned system }\end{array}$ \\
\hline $\mathrm{Ag} / \mathrm{Zn}$ & 450 & 200 & $\begin{array}{c}\text { Excess } \mathrm{Zn} \text { required, } \\
\text { low charge rate }\end{array}$ \\
\hline $\mathrm{Li} / \mathrm{LiCoO}_{2}$ & 735 & 150 & $\begin{array}{c}\text { Poor cycle life, } \\
\text { high capacity fade }\end{array}$ \\
\hline $\mathbf{L i} / \mathrm{AlFeS}_{2}$ & 515 & 150 & $\begin{array}{c}\geq 400^{\circ} \mathrm{C} \text { thermal } \\
\text { management }\end{array}$ \\
\hline $\mathrm{Na} / \mathrm{S}$ & 1180 & 150 & $\begin{array}{c}\sim 350^{\circ} \mathrm{C} \text { thermal } \\
\text { management }\end{array}$ \\
\hline $\mathbf{L i} / \mathbf{T i S}_{2}$ & 470 & 130 & $\begin{array}{l}\sim 50 \% \text { DOD for high } \\
\text { cycle life ( } 900 \text { cycles) }\end{array}$ \\
\hline Li/ion & 700 & 100 & $\begin{array}{l}\text { Marginal improvement } \\
\text { for larger cells } \\
\end{array}$ \\
\hline $\mathrm{Ni} / \mathbf{Z n}$ & 305 & 90 & $\begin{array}{l}\text { Excess Zn required, } \\
\text { low specific energy }\end{array}$ \\
\hline $\mathrm{Ni} / \mathbf{M H}_{\mathrm{x}}$ & 470 & 70 & $\mathrm{MH}_{\mathrm{X}}$ is metal hydride \\
\hline $\mathrm{Ni} / \mathrm{H}_{2}$ & 470 & 60 & Low specific energy \\
\hline $\mathrm{Ni} / \mathrm{Cd}$ & 240 & 60 & Low specific energy \\
\hline Pb/acid & 170 & 50 & Low specific energy \\
\hline
\end{tabular}

Figure 2. Theoretical and packaged specific energy for URFCs and rechargeable batteries. ${ }^{[2]}$

${ }^{*} \mathrm{Li}-\mathrm{SPE} / \mathrm{MO}_{\mathrm{x}}$ is Li-solid polymer electrolyte/metal oxide system packaged for unmanned systems. 


\section{MITLITSKY ET AL}

$-3-$

A variety of hydrogen storage technologies are being considered for vehicular applications, including: physical storage, chemical carriers, gas-on-solid adsorption, and metal hydrides. These techniques have been compared in terms of weight, volume, complexity, cost, dormancy, and safety. ${ }_{.}^{\left[{ }^{5,6]}\right.}$ By the criteria discussed in those references, compressed gas storage using carbon fiber composite pressure vessels wound onto metal or plastic liners has been identified as one of the best near-term technologies.

The development of lightweight composite storage tanks using polymeric bladders as the inflatable mandrel and integral liner has been partially performed under a program funded by the DOE, Office of Transportation Technologies, in conjunction with Ford Motor Company. Tanks fabricated using this technology have advanced the state-of-the-art in tank performance factors, while achieving the high cycle life capability of thick metal or polymeric liners. Since the liners are thin and lightweight, the weight and volume penalties associated with packaging tanks into multiple units is reduced. The performance factor of a bladder lined tank using lower strength/less expensive carbon fibers (such as T700S or Panex 33) can match the performance factor of similar tanks with thick liners using higher strength/more expensive carbon fiber (such as T1000G). This is important because tank cost is dominated by fiber cost and the fiber cost per tank for T1000G is currently a factor of three-four times that of T700S or Panex 33.

Vehicles using rechargeable batteries have limited range per charge ( $<200$ miles) due to low specific energy as shown in figure 2. Vehicles using lightweight pressure vessels for the onboard storage of hydrogen, combined with lightweight primary fuel cells can have greater than 350 mile range, could be rapidly refueled by sources of high pressure hydrogen (when available), and will be compatible with home electrolysis units. Such systems will require a hydrogen infrastructure or procurement of home electrolysis unit. Vehicles using lightweight pressure vessels and lightweight regenerative fuel cells will have the features of primary fuel cells and a rechargeable specific energy that is greater than $400 \mathrm{Wh} / \mathrm{kg}$. Such systems would be dual-fueled vehicles that can use the existing electrical infrastructure, can utilize hydrogen infrastructure for rapid refueling (when available), enable regenerative braking by electrolysis, enable power peaking by oxygen supercharging, and will be cost competitive with primary hydrogen fuel cell vehicles.

\section{ACKNOWLEDGMENTS}

P.J. Regna (Aero Tec Laboratories), C.J. Anderson, G. Kendall, W.M. Parks, and D.H. Swan (AeroVironment), B.D. James and I.F. Kuhn, Jr. (Directed Technologies), S. Chalk and J. Milliken (DOE), R.C. Haddock and R. Willardson (EDO Fiber Science), G.H. Purnell and R.I. Sims (Ford), J.F. McElroy, T.M. Molter, L. Moulthrop, and R. Zhang (Hamilton Standard), M.L. Dickerson, M.J. Eckart, W. Jensen, and J.C. Whitehead (LLNL), J. Baer-Reidhart (NASA Dryden). This work was performed under the auspices of the U.S. DOE by LLNL under contract number W-7405-Eng 48 .

\section{REFERENCES}

1. F. Mitlitsky, B. Myers, and F. Magnotta, "Lightweight bladder lined pressure vessels," Disclosure and Record of Invention, DOE Case No. IL-9722, 1995.

2. F. Mitlitsky, N.J. Colella, B. Myers, and C.J. Anderson, "Regenerative Fuel Cells for High Altitude Long Endurance Solar Powered Aircraft," Proc. $28^{\text {th }}$ IECEC, Vol. 1,. pp. 1255-1262, Aug. 8-13, 1993 (UCRL-JC-113485).

3. F. Mitlitsky, N.J. Colella, and B. Myers, "Unitized Regenerative Fuel Cells for Solar Rechargeable Aircraft and Zero Emission Vehicles," 1994 Fuel Cell Seminar, pp. 624-627, Nov. 28-Dec. 1, 1994 (UCRL-JC-117130 and UCRL-MI-117130). 


\section{MITLITSKY ET AL}

$-4-$

4. P.J. Chludzinski, I.F. Danzig, A.P. Fickett, and D.W. Craft, "Regenerative fuel cell development for satellite secondary power," General Electric Company, Technical Report AFAPL-TR-73-34, Jun. 1973.

5. F. Mitlitsky and B. Myers, "Development of an advanced, composite, lightweight, high pressure storage tank for on-board storage of compressed hydrogen," Fuel Cells for Transportation TOPTEC: Addressing the Fuel Infrastructure Issue, Alexandria, VA, April 12, 1996 (UCRL-MI-123802).

6. B.D. James, G.N. Baum, F.D. Lomax, Jr., C.E. Thomas, and I.F. Kuhn, Jr., "Comparison of onboard hydrogen storage for fuel cell vehicles," Ford Motor Company/DOE, February, 1996. 


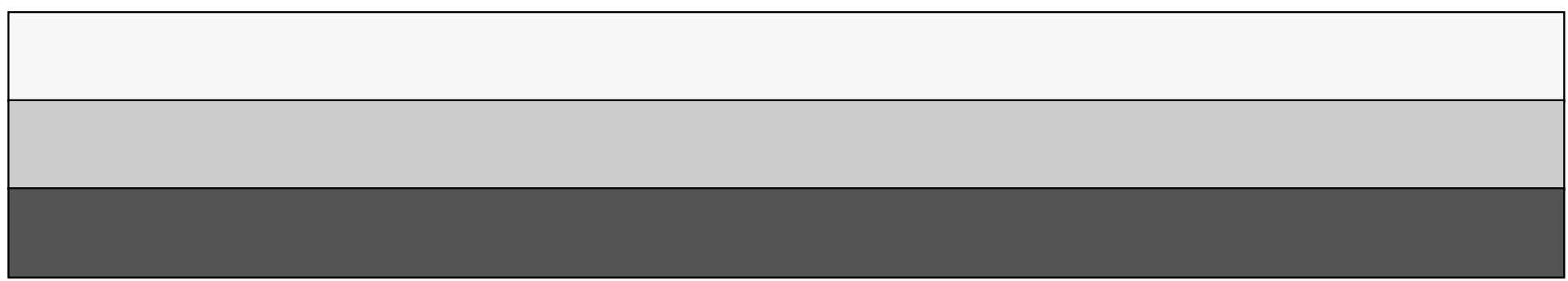

